

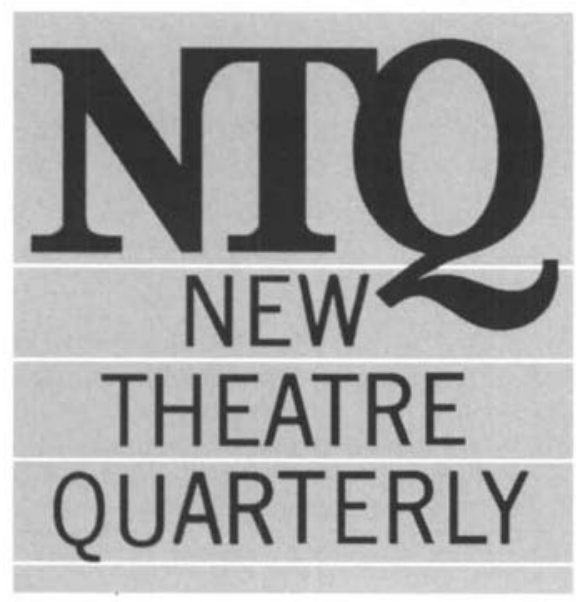

Successor journal to Theatre Quarterly (1971-1981)

VOLUME XV PART 3 (NTQ 59)

\section{AUGUST 1999}

\section{Editors \\ CLIVE BARKER \\ SIMON TRUSSLER}

Advisory Editors: Arthur Ballet, Eugenio Barba, Susan Bassnett, Tracy Davis, Martin Esslin, Maggie Gale (Book Reviews Editor), Lizbeth Goodman, Peter Hepple, Ian Herbert, Jan Kott,

Brian Murphy, Sarah Stanton, Ian Watson

\section{Contents}

JOHN RUSSELL BROWN

195 Cross-Dressed Actors and their Audiences: Kate Valk's Emperor Jones and Shakespeare's Juliet how presentation and representation mark the gender difference

MARIA M. DELGADO

204 'Making Theatre, Making a Society': an Introduction to the Work of Peter Sellars overview of the innovative director's work in live performance

BELLA MERLIN

218 Which Came First: the System or The Seagull?

Chekhov, Stanislavsky, and the dialectics of 'realistic' staging

BELLA MERLIN

228 Albert Filozov and the Method of Physical Actions different strands of Stanislavskian tradition in tension and realization

IAN HERBERT

236 Writing in the Dark:

Fifty Years of British Theatre Criticism

the changing British theatre as seen from the seats on the aisle

SONIA MASSAI

247 Stage over Study: Charles Marowitz, Edward Bond, and Recent Materialist Approaches to Shakespeare how revisionist adaptations anticipated cultural materialist criticism

ROBERT LYONS 256 In Search of Brecht: Notes from Rehearsals of 'Leben des Galilei' at the Berliner Ensemble, 1997 confronting Brecht's most autobiographical play for the millennium

280 Sarah Kane: an Appreciation

the writer who helped to define the theatrical mood of the 'nineties

282 NTQ Book Reviews

edited by Maggie Gale 


\section{Editorial Enquiries (please note change of editorial address) Oldstairs, Kingsdown, Deal, Kent CT14 8ES, England}

Unsolicited manuscripts are considered for publication in New Theatre Quarterly. They should be sent to Simon Trussler at the above address, but unless accompanied by a stamped addressed envelope (UK stamp or international reply coupons) return cannot be guaranteed. Contributors should follow the journal's house style as closely as possible. A style sheet is available on request.

\section{Subscriptions}

New Theatre Quarterly (ISSN: 0266-464X) is published quarterly by Cambridge University Press, The Edinburgh Building, Shaftesbury Road, Cambridge CB2 2RU, UK, and The Journals Department, 40 West 20th Street, New York, NY 10011-4211, USA.

Four parts form a volume. The subscription price, which includes postage (excluding VAT), of Volume XV, 1999, is $£ 52.00$ (US\$88.00 in the USA, Canada and Mexico) for institutions, $£ 30.00$ (US\$48.00) for individuals ordering direct from the publishers and certifying that the Journal is for their personal use. Single parts cost $£ 14.00$ (US $\$ 24.00$ in the USA, Canada and Mexico) plus postage. EU subscribers (outside the UK) who are not registered for VAT should add VAT at their country's rate. VAT registered subscribers should provide their VAT registration number. Prices include delivery by air. Japanese prices for institutions are available from Kinokuniya Company Ltd., P.O. Box 55, Chitose, Tokyo 156, Japan.

Orders, which must be accompanied by payment, may be sent to a bookseller or to the publishers (in the USA, Canada and Mexico to the North American Branch). Periodicals postage paid at New York, NY, and at additional mailing offices. POSTMASTER: send address changes in the USA, Canada and Mexico to New Theatre Quarterly, Cambridge University Press, The Journals Department, 40 West 20th Street, New York, NY 10011-4211.

Claims for missing issues will only be considered if made immediately on receipt of the following issue.

Information on New Theatre Quarterly and all other Cambridge journals can be accessed via www.cup.cam.ac.uk and in North America via www.cup.org.

Copying: This journal is registered with the Copyright Clearance Center, 222 Rosewood Drive, Danvers, MA 01923. Organizations in the USA who are registered with C.C.C. may therefore copy material (beyond the limits permitted by Sections 107 and 108 of US copyright law) subject to payment to C.C.C. of the per-copy fee of $\$ 9.50$. This consent does not extend to multiple copying for promotional or commercial purposes. Code $0266-464 X / 99 \$ 9.50$.

Organizations authorized by the Copyright Licensing Agency may also copy material subject to the usual conditions. ISI Tear Sheet Service, 35021 Market Street, Philadelphia, Pennsylvania 19104, USA, is authorized to supply single copies of separate articles for private use only.

For all other use, permission should be sought from the Cambridge University Press.

\section{(C) 1999 CAMBRIDGE UNIVERSITY PRESS}

The Edinburgh Building, Cambridge CB2 2RU, United Kingdom

40 West 20th Street, New York, NY 10011-4211, USA

10 Stamford Road, Oakleigh, Melbourne 3166, Australia

Typeset by Country Setting, Kingsdown, Deal, Kent CT14 8ES

Printed and bound in the United Kingdom at the University Press, Cambridge 